\title{
Önemli Muhasebe Tahminlerinin Kilit Denetim Konuları Çerçevesinde İncelenmesi
}

\author{
Review of Critical Accounting Estimates in the Context of Key \\ Audit Matters
}

\author{
Ayça Zeynep Süer ${ }^{1}$ \\ 'Doç.Dr., İstanbul Üniversitesi, İşletme Fakültesi, Muhasebe Anabilim Dalı, İstanbul, Türkiye \\ ORCID: A.Z.S. 0000-0003-3421-9759
}

\section{ÖZ}

Belirsizlik faktörlerinin giderek yoğunlaştığı günümüz koşullarında önemli muhasebe tahmin ve varsayımlarına dayalı olarak finansal tablolara alınan tutarların büyüklüğü artmaktadır. Muhasebe tahmin ve varsayımlarının yüksek düzeyde belirsizlik içeren doğası sebebiyle bağımsız denetim sırasında denetçi için önem arz eden konular arasında yer alarak denetim raporlarında kilit denetim konularına yansıması beklenmektedir. Bu çalışmada, BİST30 endeksinde yer alan şirketlerin 2020 yılı finansal tablolarının dipnotlarında açıkladıkları "Önemli Muhasebe Tahmin ve Varsayımları" ve bağımsız denetim raporlarında yer alan "Kilit Denetim Konuları” incelenmiştir. İnceleme kapsamında; BİST30 şirketleri sektörlerine göre sınıflandırılarak kilit denetim konularına yansıyan önemli muhasebe tahmin ve varsayımlarının tespiti yapılmıştır.

Anahtar kelimeler: Önemli Muhasebe Tahminleri, Kilit Denetim Konuları, Finansal Raporlar, Denetim Raporları

\section{ABSTRACT}

In contemporary times, as factors of uncertainty are increasingly intensified, the amounts included in financial statements based on critical accounting estimate (CAE) disclosures are increasing. Due to the nature of accounting estimates and assumptions, with attending high levels of uncertainty, they are among the significant issues of focus for auditors and are expected to reflect key audit matters in audit reports. In this study, the "Critical Accounting Estimates and Assumptions" announced in the footnotes of the 2020 financial statements of companies included in the Borsa Istanbul 30 (BIST30) index and "Key Audit Matters" (KAMs) in the companies' audit reports were examined. BIST30 companies were then classified according to sector and the CAE disclosures and assumptions reflected in the KAMs were determined. This study provide insight into the interrelation between CAE disclosures and KAMs, and also aims to be informative to financial statement users regarding to pervasive impact of CAE on financial reports.

Keywords: Critical accounting estimates, key audit matters, financial reports, audit reports

Başvuru/Submitted: 31.05.2021 Revizyon Talebi/Revision Requested: 14.06.2021 Son Revizyon/Last Revision Received: 25.06 .2021 Kabul/Accepted: 16.07.2021 Sorumlu yazar/Corresponding author: Ayça Zeynep Süer / ayca@istanbu.edu.tr 


\section{Extended Abstract}

Critical accounting estimate (CAE) disclosures potentially include greater uncertainty, given the subjective nature of the management estimation and judgment process. According to the Public Company Accounting Oversight Board (PCAOB), accounting estimates are included in financial statements for which the measurement of some amounts or the valuation of some accounts is uncertain.

Accounting accruals are managers' subjective estimates of future outcomes that cannot be objectively verified by auditors prior to their occurrence, such as estimates of useful lives and residual values for depreciation, allowance for doubtful accounts, impairment of assets, warranties, and provisions (Francis and Krishnan, 1999).

The independent auditor's primary objective is to ensure the reader of a corporation's financial statements that those financial statements present information "fairly." To accomplish this, auditors issue an appropriate audit report to accompany the financial statements in companies' annual reports. By necessity, financial statements contain many estimates and judgments. The auditor must evaluate the degree and type of uncertainty associated with components of financial statements (Buchman \& Collins, 1998); therefore, CAE disclosures have an unquestionable impact on the audit process.

Auditors should evaluate indicators of possible bias in management's estimates, assumptions, and judgments. For example, the auditor may become aware of management bias in the development of accounting estimates. (Eilifsen, Messier, Glover, \& Prawitt, 2010).

Auditors are the arbiters of the reliability of companies' financial reports. The increasing importance of complex estimates and opportunities for the imposition of management bias that estimates provide jointly imply that audit quality in this area is critical to the reliability of financial reports. However, accounting estimates are challenging to audit, as they represent subjective forecasts of future events. For accounts based on historical cost, auditors can verify the accuracy of those historical numbers; however, for estimates, the auditor's task is to evaluate the reasonableness of an estimate (Griffin, Hammersley, \& Kadous, 2015).

Standard-setters and audit regulators worldwide, including the Public Company Accounting Oversight Board (PCAOB) and the International Auditing and Assurance Standards Board (IAASB), initiated an expanded audit reporting model to respond to concerns about the lack of transparency in auditor reports. One significant change in both PCAOB and IAASB amendments is the implementation of key audit matters (KAMs), which require new disclosure requirements for providing information about significant matters auditors encountered during an audit (Gold, Heilmann, Pott, \& Rematzki, 2020). Since CAEs with inherent measurement uncertainty are pervasive in financial reporting. It is expected that auditors take them into consideration as KAMs by disclosing them in the auditor's report.

Common estimates, such as allowance for doubtful accounts and those related to depreciation of assets, will most likely require the least additional effort to comply with the statement's requirements, as the estimation process is relatively straightforward and already well known and understood by auditors. Estimates, such as net realizable value of inventories, which depend on forecasts of future prices and costs, may require additional significant effort for auditors to comply because of the complexity of the estimation process (Harsha \& Peacock, 1989).

This study aims to analyze the relationship between CAE disclosures and KAMs and evaluate the possible relational cues in KAMs that demonstrate CAE disclosures in the 2020 annual reports published by Borsa Istanbul 30 (BIST30) companies. To gain insight regarding the interrelation between CAE disclosures and KAMs, BIST30 companies were classified according to sector and the CAE disclosures and assumptions reflected in the KAMs were determined. 


\section{Giriş}

Gelecek finansal dönemlerde, varlık ve yükümlülüklerin kayıtlı değerinde düzeltmelere neden olma riski olan tahmin ve varsayımlar, ekonomik belirsizliğin arttı̆̆ bir dönemde daha çok dikkat edilmesi gereken bir husus haline gelmektedir. Dünya ekonomik düzeninde dönemsel olarak yaşanan değişimlerin, yeniliklerin, olağan ve olağandışı faktörlerin etkisiyle olumlu gelişmeler yaşanabileceği gibi olumsuz gelişmeler de söz konusu olabilmektedir. Sonuçlarının genişliği ve muazzam düzeyde getirdiği belirsizlikler bakımından tamamen farklı bir boyuta sahip olan Covid-19 salgınının (Barnoussi, Howieson, \& Beest, F. 2020) küresel makroekonomik koşullar üzerindeki olası etkilerinin de muhasebe tahminlerine dahil edilerek finansal raporların hazırlandığı dönemler yaşanmaktadır.

2000'li yılların başında yaşanan muhasebe skandalları ve akabinde kamu güveninin yeniden inşası için getirilen düzenlemeler ile muhasebe standartlarında kural odaklılıktan ilke odaklılığa geçiş olmuştur. Bu durum da beraberinde finansal raporlamada insan boyutunun ön plana çıkarılarak varsayım ve tahmin içeren standartları getirmiştir. İlke temelli standartlarla işletmelerin finansal raporlamaları kapsamında ilk kayda alma, ölçme, sunum ve açıklamalarında mesleki yargılar, önemli muhasebe tahminleri, varsayımlar ve değerlendirmeler yer almaya başlamıştır (Süer, 2016). Denetim standartları kapsamında ise; önemli muhasebe tahminlerine, yargılara ve gelecekteki olayların değerlendirilmesine dayanan tutarların ölçümünün içerdiği belirsizliklerin finansal tablo kullanıcıları tarafından kabul edildiği varsayılarak bağımsız denetim gerçekleştirilmektedir.

Son yıllarda denetim standartları kapsamında getirilen yeni düzenlemelerle, denetim sırasında denetçi için önem arz eden kilit denetim konularına denetim raporlarında yer verilmektedir. Bu sayede yapıları gereği karmaşı bir sürecin sonunda oluşturulan ve öznel muhakeme gerektiren muhasebe tahminlerinin denetimde nasıl ele alındığı da denetim raporları aracılı̆̆ıla kamuya açıklanabilmektedir (Pinello, Puschaver, \& Volkan, 2020).

$\mathrm{Bu}$ çalışmada, önemli muhasebe tahminleri ve kilit denetim konuları etkileşimi ele alınarak 31 Aralık 2020 tarihi itibarıyla düzenlenen finansal tablolarda önemli tahmin ve varsayımlara ilişkin açıklanan unsurların bağımsız denetim raporlarında denetçilerin bildirdikleri kilit denetim konularına ne ölçüde yansıdığı incelenmiştir.

\section{2. Önemli Muhasebe Tahminleri}

Halka Açı Şirket Muhasebe Gözetim Kurulu (Public Company Accounting Oversight Board-PCAOB) ve Uluslararası Denetim ve Güvence Standartları Kurulu (International Auditing and Assurance Standards Board-IAASB) gibi standart düzenleyiciler, muhasebe tahminlerinin daha geniş kapsamlı açıklamalar gerektirdiğini düşündükleri için halen bu konuda çalışmalarına devam etmekte ve ilgili standartları güncellemektedir.

IAASB Başkanı, finansal raporlarda kelimelerin ve değerlendirmelerin daha büyük rol oynadığını, değerleme sürecinin artık daha fazla açıklamaya ihtiyacı olduğunu vurgulayarak, bu açıklamaların tahmin ve varsayımları gerektirdiğini belirtmiş̧tir. Beklenen kredi zararları gibi kalemlerin artık finansal tabloların büyük bir bölümünü oluşturduğuna dikkat çekmiştir (Brouwer, Eimers \& Langendijk, 2016).

IAASB'nin yaptığı bir çalışmada, finansal tablolardaki bilgilerle ilgili üç kaygı belirlenmiştir: - yeterli alakalı bilginin olmayışı, -çok fazla alakasız bilginin oluşu ve - etkisiz bir şekilde iletilen bilginin varlığı. Etkisiz iletişim aynı zamanda finansal tabloları daha az anlaşılır kılmakta ve bu da yatırımcıların şirketin beklentilerine ilişkin algılarındaki belirsizliği artırarak şirketler için daha yüksek sermaye maliyetine yol açabilir. Finansal tablolarda etkin bilgi iletişimi, daha iyi yatırım kararlarına ve şirketler için daha düşük sermaye maliyetine katkıda bulunabilir (IFRS, 2017). Finansal raporlama ile daha etkin bir iletişimin sağlanması için önemli muhasebe değerlendirme, tahmin ve varsayımlarının net ve anlaşılabilir bir şekilde sunulması gerekir.

Finansal raporlamanın temelini oluşturan tahakkukların büyük bir kısmı tahminlere dayanmaktadır. Tahakkuklar, yöneticilerin gelecekteki sonuçlara ilişkin öznel tahminleri olup amortisman için faydalı ömür ve hurda değer tahminleri, şüpheli alacaklar karşılığı, varlıkların değer düşüklüğü, garanti gider karşılıkları gibi örneklerinden anlaşılabileceği üzere 
gerçekleşmeden önce denetçiler tarafından objektif olarak doğrulanmaları mümkün olmayan unsurlardır. Tahakkuk esaslı kazançlar, yönetimsel takdir yetkisini içerdiği için doğal olarak kârlar, nakit akışlarından daha belirsiz hale gelmektedir. Bu durum da, yüksek tahakkuklara sahip firmaların denetimlerinin, potansiyel tahmin hatası etkisiyle düşük tahakkuklara sahip firmaların denetimlerinden daha fazla belirsizlik oluşturmasına neden olmaktadır (Francis ve Krishnan, 1999).

Amerikan Sermaye Piyasası Kurulu (U.S. Securities and Exchange Commission-SEC) tarafindan 2002 y1linda muhasebe tahminlerini de kapsayan önemli muhasebe politikalarına ilişkin önerilen düzenlemede; bir muhasebe tahmininin, iki kriteri karşılaması durumunda, önemli muhasebe tahmini sayılacă̆ı belirtilmiştir. İlk olarak, muhasebe tahmini, yönetimin yüksek derecede belirsiz olan hususlar hakkında varsayımlarda bulunmasını gerektirmelidir. İkinci olarak, cari dönemde farklı varsayımlar doğrultusunda yapılan muhasebe tahminlerinin veya dönemden döneme makul ölçüde olması muhtemel muhasebe tahminindeki değişiklikler işletmenin finansal durumunda ve faaliyet sonuçlarında önemli bir etkiye sahip olmalıdır (Bauman ve Shaw, 2014). Örneğin, yüksek ölçüde belirsizlik içeren tahmin ve varsayıma dayalı işlemlerden biri de -ülkemizde 2018 yılından itibaren uygulanmakta olan " Türkiye Finansal Raporlama Standardı (TFRS) 9: Finansal Araçlar” uyarınca - finansal varlıklar için kredi zararı karşılığının (değer düşüklüğü) kapsamının belirlenmesidir. Finansal varlıklar için kredi zararı karşılığı, temerrüt riski ve beklenen zarar oranları hakkındaki varsayımlara dayanmaktadır. Farklı varsayımların kullanılması, farklı beklenen kredi zararı tahminleri üretebilir ve ileriye dönük makroekonomik senaryoların dahil edilmesi muhakeme gerektirir. Normalde çok faydalı olan bu modelleri, içinde yaşadığımız dönemde salgın etkisi altında olan ekonomik koşullarda uygulamak işletmeleri zorlamaktadır. Kredi zarar riskinin yanlış ölçülmesini önlemek için ileriye dönük makroekonomik faktörlerin tahminlerini olası çoklu senaryolara dahil edilmesi söz konusudur (Barnoussi ve ark., 2020).

\section{Kilit Denetim Konuları}

Denetim raporlarının standart cümlelerden oluştuğuna yönelik eleştiriler ve daha şeffaf, işletmeye özel denetim raporlarına olan talep sonucu IAASB raporlama standartları ile ilgili yeni düzenlemeler yapmıştır. Yapılan düzenlemeler ile bağımsız denetim raporlarının işletmeye özgü geçerli bilgiler içermesi ve denetim esnasında ortaya çıkan en önemli hususları yansıtması beklenmektedir (Türel ve Türel, 2016).

Denetim raporlarında kilit denetim konularının sunulmasıyla; denetçi ile işletme yöneticileri ve denetim komitesi arasındaki iletişimin arttırılması, işletme yönetimi tarafından finansal tablolarda yapılan açıklamalara/verilen bilgilere daha fazla dikkat çekilmesi ve aynı zamanda denetimde şeffaflık ve kalitenin artmasının sağlanması hedeflenmiştir (Kavut ve Güngör, 2018). Bu süreçte ortaya çıkan yeni denetim raporu, denetçi ve finansal tablo kullanıcıları arasındaki en görünür ve etkin iletişim aracını oluşturmaktadır (Carson, Fargher, \& Zhan, 2016).

Kilit denetim konularında sunulan bilgilerin kullanıcılara fayda sağlaması için standart bir metine dayanmadan işletmeye özgü olması gerekir. Bu açıdan denetçinin kilit denetim konularını, standardın getirdiği bir zorunluluk olarak değil, kullanıcılarla iletişime geçebileceği ve bilgi değeri yüksek bir alan olarak ele almasının önemli olduğu düşünülmektedir (Sarısoy ve Kepçe, 2019).

Cari dönemdeki kilit denetim konuları hem sayısal hem de içerik olarak, bir sonraki dönemde denetçiye, denetimin planlanma aşamasından itibaren özellikle denetim yaklaşımının güvenilirliğini ve denetimin kalitesini artırmaya katkıda bulunmak için önemli alanlar ve sistemlere yönelik derinlemesine denetim testleri oluşturması için rehberlik edebilir (Grosu Robu, \& Istrate, 2020).

Kilit denetim konuları bildiriminde bir adım daha ileri gidip belirsizliğin nerede ve ne ölçüde olduğuna dair daha eksiksiz bir özetin mümkün olup olmayacağı merak edilmektedir. Örneğin, önemli muhasebe tahminleri arasında uygun olanlar için denetçinin tahmin aralıkları oluşturması kullanıcılar için değerli olabilir. Ancak denetim görüşü finansal tablolara ilişkin olduğundan, denetim mesleği geleneksel olarak finansal tablolarda yer alan bilgilerin ötesinde bilgi sağlama konusunda genel olarak geride durmaktadır (Zhang ve Pany, 2021). 
Kilit denetim konuları aracılığıyla daha fazla şeffaflık ve daha yüksek hesap verebilirlik baskısı, yöneticilerin kilit denetim konuları varlığında kararlarını daha dikkatli bir şekilde almalarına neden olarak finansal raporlama kalitesinin iyileştirilmesi beklenmektedir (Gold ve ark., 2020).

\section{4. Önemli Muhasebe Tahmin Açıklamaları ve Kilit Denetim Konuları İlişkisi}

Muhasebe standartları gereğince yapılan önemli muhasebe tahminlerine ilişkin açıklamalar, finansal tablo kullanıcılarının muhasebe tahminlerine yansıyan belirsizlik derecesini değerlendirmelerine yardımcı olabilecek hususları içermektedir (Glendening, 2017). Denetim standartları kapsamında getirilen yeni düzenlemeler, yüksek düzeyde belirsizlik içerdiği için zorlayıcı bir öznel mesleki muhakeme sürecinden geçmesi gereken muhasebe tahminlerinin denetimde nasıl ele alındığını denetim raporları aracılığıyla kamuya açıklanmasını gerektirmektedir.

Denetçinin, tahmin ve varsayım içeren muhasebe politikalarını değerlendirirken yönetim tarafından önemli muhasebe tahminleri olarak tanımlanan kalemlere de odaklanacağına dair bir beklenti vardır. Kilit denetim konularına ilişkin bağımsız denetim standardı kapsamında, yönetim tarafından önemli muhasebe tahminlerini içeren alanlar olarak tanımlanan hususlar, denetçinin işletmenin denetim komitesiyle değerlendirdiği konular arasında yer almalı ve denetim raporlarında bildirilecek potansiyel kilit denetim konuları olarak değerlendirilmelidir (Pinello ve ark., 2020). Bağımsız Denetim Standardı 540'a göre- "Muhasebe Tahminlerinin ve İlgili Açıklamalarının Bağımsız Denetimi” - denetçinin, bir muhasebe tahmini ve bunun ilgili açıklamalarıyla bağlantılı bir tahmin belirsizliğine ilişkin değerlendirmesi, denetçinin dikkatini önemli ölçüde gerektiren bir konu ise, bu husus bir kilit denetim konusu olabilir (BDS 540, p. A114).

"İ̧sletme, muhasebe tahminlerine iliş̧kin sağlam bir açıklamaya yer verdiği zaman; denetçi konunun, denetimde en çok önem arz eden konulardan biri olma sebebine ve nasıl ele alındı̆̆ına yönelik açılklamanın bir parçası olarak, işletmenin yaptığı kilit varsayımlara, muhtemel sonuç aralığına yönelik açıklamalara ve önemli muhasebe tahminleri veya tahmin belirsizliğinin temel kaynaklarıyla ilgili nitel ve nicel diğer açılklamalara dikkat çekebilir.”(BDS 701, p. A41).

Finansal tablolarda kritik öneme sahip alanlar için denetçi raporunda kilit denetim konuları başlı̆̆ altında, önemli yönetim yargıları ve tahminleri, önemli ölçüm belirsizliklerine dikkat çekerek finansal tablo sunumunun daha iyi anlaşılmasına katkıda bulunabilmektedir. Örneğin denetçi, belirsizliği açılayarak ve belirsizliğin finansal tablolarda açıklandığı yere atıf vererek yönetim tarafından açıklanan bir belirsizliğe dikkat çekmek için bir "Dikkat Çekilen Husus" paragrafı da kullanabilir. PCAOB, "Dikkat Çekilen Husus" paragraflarının yalnızca yönetimin açıklamasını vurgulamakla kalmayıp, aynı zamanda yönetimin ilgili açıklamalarının bilgilendiriciliğini de artıracağını ifade etmektedir (Kelton ve Montague, 2018).

Standart düzenleyici kurumların amacı, finansal tablolar ve denetim temelinde "kullanıcıların bilgiye dayalı karar alma" yeteneğini geliştirmektir. Giderek karmaşık hale gelen finansal tablolar ve artan finansal tablo açıklamaları, kullanıııların finansal tablo bilgilerine olan dikkatlerinde seçici olmalarını gerektirmektedir. Bu noktada kilit denetim konuları, denetim raporunun diğer bölümlerinden daha fazla dikkat çekebilmektedir. Bu bölüm, kullanıcıları kilit denetim konuları ile ilgili finansal tablo açıklamasına yönlendirerek içeriğe daha fazla odaklanmalarını sağlamaktadır. Bununla birlikte, kilit denetim konularının finansal tablo açıklamalarından daha kısa olması nedeniyle kullanıcıların güvenilir kaynaktan elde ettikleri bu bilgiyi yeterli bularak finansal tablo açıklamalarına ilgilerinin azalma ihtimali de bulunmaktadır (Sirois, Bédard, \& Bera, 2018).

Bir kilit denetim konusu paragrafı, söz konusu hususun denetim açısından önemli olarak ele alınma sebebini ilgili hesaplara ve dipnot açıklamalarına atıfta bulunarak ifade eder. Örneğin, gerçeğe uygun değer tahminleriyle ilgili dipnot açıklamaları tahmin belirsizliğini vurgulayan daha geniş ve teknik analizler içerir. Diğer taraftan önemli muhasebe tahminlerini denetlemenin zorluğunu özetleyen bir kilit denetim konusu paragrafı dipnot açıklamalarında halihazırda iletilmiş ayrıntılardan türetilebilecek bilgileri sunar (Christensen, Glover \& Wolfe, 2014). 
Gerçeğe uygun değer tahminlerinin denetimlerinde tahmin belirsizliğini iki faktör oluşturmaktadır: (1) ölçüm belirsizliği (2) makroekonomik riskler (Bratten, Gaynor, McDaniel, Montague, \& Sierra, 2013). Covid-19 salgının oluşturduğu ekonomik belirsizlik ortamında işletmelerin gerçeğe uygun değer tahminlerini yaparken olası riskleri dikkate almalarını, denetçilerin de olası senaryolar dahilinde tahminleri denetlemelerini gerektirmektedir.

Christensen ve ark. (2014), önemli gerçeğe uygun değer tahminlerinin denetimini vurgulayan bir kilit denetim konusu paragrafının, daha yüksek kaynak güvenilirliği nedeniyle gerçeğe uygun değer tahmini dipnot açıklamalarından daha fazla dikkat çekeceğini ifade etmektedir. Söz konusu çalışmada gerçeğe uygun değer tahminleri genellikle denetçiler için benzersiz zorluklar oluşturduğundan, denetim raporunda kilit denetim konusu aracıllı̆ıyla yatırımcıların dikkatini bu tür zorluklara yoğunlaşmasına neden olarak, yalnızca gerçeğe uygun değer tahmini dipnot açıklamalarını alan yatırımcılara nazaran onları yatırım konusunda daha ihtiyatı hale getirebileceği öngörülmektedir.

Denetçilerin finansal tablo kullanıcıları ile iletişiminin geliştirilmesine yönelik getirilen düzenlemeler, yönetimin geçmiş dönem tahmin doğruluğu ve cari dönem ölçüm belirsizliği düzeylerine ilişkin yapıllan ek açıklamalar, gerçeğe uygun değer tahminlerinin yüksek belirsizliğinin doğrulanabilirliği hakkındaki endişeleri gidermektedir (Bell ve Griffin, 2012). Böylelikle sermaye piyasaları daha fazla gelişerek etkin hale gelebilmektedir.

Finansal raporlama kalitesi ve denetim kalitesinin, işletmenin faaliyet gösterdiği ekonomiden büyük ölçüde etkilenmesinden dolayı değişen ekonomik koşulların finansal raporlamayı ve denetim sonuçlarını nasıl etkilediğinin daha fazla dikkate alınması, finansal raporlama ve denetim hakkında daha derin bir kavrayışsağlayacaktır (Gaynor, Kelton, Mercer, \& Yohn 2016).

\section{5. Önemli Muhasebe Tahminleri ve Kilit Denetim Konuları Açısından BİST30 Şirketlerinin 2020 yılı Finansal Tablo Açıklamalarının ve Denetim Raporlarının İncelenmesi}

Tanımlayıcı araştırma içeren bu çalışmada, BİST30 endeksinde Mart 2021 itibarıyla yer alan şirketlerin 2020 yılına ait finansal raporlarına Kamuyu Aydınlatma Platformundan (KAP) ulaşılarak söz konusu şirketlerin finansal tablo dipnotlarında açıkladıkları "Önemli Muhasebe Tahminleri”" ve 2020 yılı bağımsız denetim raporlarında yer alan "Kilit Denetim Konuları" aşağıda belirtilen çerçevede incelenmiştir.

1 no.lu "Finansal Tabloların Sunuluşu" Türkiye Muhasebe Standardının (TMS) 122.paragrafında; "İşletme, önemli muhasebe politikalarıyla ya da diğer dipnotlarla birlikte, muhasebe politikalarının uygulanması sürecinde yönetimin bulunmuş olduğu ve finansal tablolara yansittlan tutarlar üzerinde en çok etkiye sahip olan tahmin içerenler dişındaki yargıları açıklar." ifadesi yer almaktadır. Aynı standardın 125.paragrafında ise; "İ̧sletme, varlı ve yükümlülüklerin defter değerinde bir sonraki hesap döneminde önemli bir düzeltme yapılmasını gerektirebilecek önemli bir risk taşlyan geleceğe yönelik olarak yaptı̆̆ varsayımlar ve raporlama dönemi sonunda mevcut olan tahminlerdeki belirsizliğin diğer ana kaynakları hakkındaki bilgileri açıklar." ifadesi yer almaktadır. Açıklanan varsayımların ve tahminlerdeki belirsizliğin diğer kaynaklarının; yönetimin en zor, öznel veya karmaşı yargılarda bulunmasını gerektiren tahminlerle ilgili olduğu vurgulanmıştır.

$\mathrm{Bu}$ ifadelere ek olarak, standartta muhasebe politikalarının uygulanması sürecinde yönetimin bulunduğu belirli yargılara ilişkin açıklamalar, tahminlerdeki belirsizliğin kaynaklarına ilişkin öngörülen açıklamalarla ilgili olmadığı belirtilmiştir. Bu nedenle çalışma kapsamında işletmelerin finansal tablo açıklamalarında "Önemli Muhasebe Değerlendirme, Tahmin ve Varsayımları" başlığı altında sunulan bilgiler incelenmiştir. Ancak bankaların finansal tablo açıklamalarında muhasebe tahminlerine ilişkin ayrı bir başlık bulunmadığı için "tahmin ve varsayım" ifadelerinin geçtiği dipnot açıklamalarındaki önemli muhasebe tahminleri dikkate alınmıştır. BİST30 şirketlerinin 2020 faaliyet dönemine ait sunulan finansal raporları kapsamında açıkladıkları önemli muhasebe tahminlerinin kilit denetim konularına yansımasını incelemek amacıyla muhasebe tahminleri aynı döneme ait bağımsız denetçi raporunda kilit denetim konusu olarak bildirilip/bildirilmediği tespit edilerek Ek 1'de sunulan tabloda özetlenmiştir. Söz konusu tablodaki bilgiler doğrultusunda sektörler bazında şirketlerin kilit denetim konularına yansıyan önemli muhasebe tahmin ve varsayımları aşağıda açıklanmıştır. Şirketler 
tarafından farklı kelimelerle ifade edilen ancak aynı anlama gelen önemli muhasebe tahminleri ortak başlık altında ele alınmıştır.

Mali kuruluşlar sektöründe faaliyet gösteren şirketlerin bağımsız denetim raporlarında kilit denetim konularına yansıyan önemli muhasebe tahmin ve varsayımları;

- Finansal varlıklarda değer düşüklüğ̈̈: Beklenen kredi zararları karşılığ

- Emeklilik haklarından doğan yükümlülükler

- Yatırım amaçlı gayrimenkuller

- Ertelenmiş vergi varlıklarının geri kazanılabilirliği

- Sınırsız ömürlü maddi olmayan duran varlıklar değer düşüklüğü testleri

- İmtiyaz sözleşmelerinden doğan haklar ve şerefiyenin geri kazanılabilirliği: Değer düşüklüğü analizlerinde kullanılan iskonto oranlarına ilişkin duyarlılık analizleri

- Uzun vadeli sözleşmeler için finansal tablolara alınan hasılat

- Türev araçların ve diğer finansal araçların gerçeğe uygun değerleri

İmalat sektöründe faaliyet gösteren şirketlerin bağımsız denetim raporlarında kilit denetim konularına yansıyan önemli muhasebe tahmin ve varsayımlar1;

- Sınırsız faydalı ömre sahip olan maddi olmayan duran varlıklar ve şerefiye değer düşüklüğü tespit çalışması

- Net gerçekleşebilir değer

- Ertelenmiş vergi varlıklarının geri kazanılabilirliği

- Edim yükümlülüklerinin yerine getirilme zamanının belirlenmesindeki hükümler

- Yatırım amaçlı gayrimenkullerin gerçeğe uygun değer ölçümü

- Arsa ve arazilerin gerçeğe uygun değerlemesi

Ulaştırma, depolama ve haberleşme sektöründe faaliyet gösteren şirketlerin bağımsız denetim raporlarında kilit denetim konularına yansıyan önemli muhasebe tahmin ve varsayımları;

- Teslim bakım karşılıkları

- Ertelenmiş vergi varlığı

- Karşılıklar, koşullu varlıklar ve borçlar

- Gerçeğe uygun değer belirleme süreci

- S1k uçuş programı yükümlülüğü hesaplaması

- Maddi varlıkların faydalı ömürleri ve hurda değerleri

- Şerefiyenin değer düşüklüğü testinde kullanılan varsayımlar 
Madencilik ve taş ocakçılığı sektöründe faaliyet gösteren şirketlerin bağımsız denetim raporlarında kilit denetim konularına yansıyan önemli muhasebe tahmin ve varsayımları;

- Maden varlıkları

Teknoloji sektöründe faaliyet gösteren şirketlerin bağımsız denetim raporlarında kilit denetim konularına yansıyan önemli muhasebe tahmin ve varsayımları;

- Eskalasyon: TFRS 15 “Müşteri Sözleşmelerinden Hasılat” kapsamındaki projelerden eskalasyona tabi sözleşmeler

- Garanti gider karşılı̆̆1

Ticaret sektöründe faaliyet gösteren şirketlerin bağımsız denetim raporlarında kilit denetim konularına yansıyan önemli muhasebe tahmin ve varsayımlar1;

- Kullanım hakkı varlık ve yükümlülüklerinin hesaplamasında nakit akışlarının bilanço tarihine indirgenmesinde kullanılan yıllık iskonto oranının ve kiralama süresinin belirlenmesi

İnceleme sonucunda BİST30 şirketlerinin finansal tablo açıklamalarında 190 adet önemli muhasebe tahmin ve varsayımından 46'sının kilit denetim konusu olarak denetim raporunda bildirildiği tespit edilmiştir. Başka bir deyişle BİST30 şirketlerinin önemli muhasebe tahmin ve varsayımlarının yaklaşı \% 24’ü bağımsız denetim sürecinde kilit denetim konusu olarak ele alınmıştır. Her bir şirketin önemli muhasebe tahminlerinden kilit denetim konularına yansıyan tahminlerinin oranlarının ortalamasının da yaklaşık \% 26 olduğu tespit edilmiştir. Önemli muhasebe tahmin açıklamaları arasında kilit denetim konusu olarak ele alınan en sık tekrarlanan tahminlerin "Beklenen kredi zarar hesaplaması" ve "Emeklilik hakları" konusu olduğu gözlemlenmiştir.

BİST30 şirketlerinin denetim raporlarında yer alan toplam 65 adet kilit denetim konusunun 46'sı (yaklaşı1k \% 71 'i) şirketlerin finansal tablo açıklamalarında önemli muhasebe tahmin ve varsayımları arasında bulunmaktadır. Bu bulguya göre ve finansal raporlama standartlarında tahmin ve varsayım gerektiren unsurların yoğunluğu nedeniyle muhasebe tahminlerinin finansal tabloların denetiminde denetçi için önem arz eden konuların başında geldiğini söylemek mümkündür.

\section{Sonuç}

Finansal bilginin faydalı olması için, ihtiyaca uygun olması ve sunmayı amaçladığı hususu gerçeğe uygun olarak sunması gerekir. Finansal bilginin faydası; söz konusu bilginin karşılaştırılabilir, doğrulanabilir, zamanında sunulmuş ve anlaşılabilir olması durumunda arttırılmış olur (Kavramsal Çerçeve, 2.4). Covid-19 salgınının neden olduğu olumsuz ekonomik koşullar ortamında faydalı finansal bilginin üretilebilmesi için finansal raporlama ve denetim sürecinde normalden çok daha fazla özen ve hassas değerlendirme gerekeceği açıktır.

Muhasebe tahminlerindeki öznelliğe bağlı olarak, tahminlerin geliştirilmesi ve denetlenmesi hem yönetim hem de denetçiler için zorluklar ortaya çıkarır. Tahmin geliştirmede yönetim yanlılığı potansiyeli ve finansal raporlama sürecinde tahminlerin artan yaygınlığı ve önemi göz önüne alındığında denetçiler önemli bir rol oynamaktadır (Stuber ve Hogan, 2021).

Bu çalışmada, BİST30 şirketlerinin 2020 yılı finansal tablo dipnotlarında açıkladıkları “Önemli Muhasebe Tahmin ve Varsayımları” ve bağımsız denetim raporlarında yer alan "Kilit Denetim Konuları” incelenmiştir. İnceleme kapsamında; BİST30 şirketleri sektörlerine göre sınıflandırılarak kilit denetim konularına yansıyan önemli muhasebe tahmin ve varsayımlarının tespiti yapılmıştır. İnceleme sonucunda BİST30 şirketlerinin önemli muhasebe tahmin ve varsayımlarının \%24'ü denetim sürecinde kilit denetim konusu olarak ele alınmıştır. Diğer taraftan BİST30 şirketlerinin denetim raporlarında yer alan kilit denetim konularının \% 71'i finansal tablo dipnotlarında önemli muhasebe tahmin ve varsayımı olarak açıklanmıştır. 
Bugünün finansal raporlamasına çok özgü olan belirsizliğin en iyi nasıl azaltılabileceğiyle ilgili sorulara cevap aranırken nitel ve nicel iletişimin varyasyonları araştırılmalıdır (Kelton ve Montague, 2018). Varsayımlardaki küçük değişikliklere duyarlı ve belirsizliği yüksek olan tahmine dayalı ölçümlere ilişkin detaylı bilgiler finansal tablo açıklamalarında sunulduğunda ve denetçiler tarafından bu hususlar denetim raporlarında kilit denetim konusu olarak bildirildiği takdirde, yüksek düzeyde belirsizliğe maruz kalan önemli muhasebe tahminlerinin etkisinin finansal tablo kullanıcıları tarafından daha iyi anlaşılacağı düşünülmektedir.

Hakem Değerlendirmesi: Dış bağımsız.

Çıkar Çatışması: Yazar çıkar çatışması bildirmemiştir.

Finansal Destek: Yazar bu çalışma için finansal destek almadığını beyan etmiştir.

Peer-review: Externally peer-reviewed.

Conflict of Interest: The author has no conflict of interest to declare.

Grant Support: The author declared that this study has received no financial support.

\section{Kaynaklar}

Barnoussi, A. E., Howieson, B., \& Van Beest, F. (2020). Prudential application of IFRS 9:(Un) fair reporting in COVID-19 crisis for banks worldwide?!. Australian Accounting Review, 30(3), 178-192.

Bauman, M. P., \& Shaw, K. W. (2014). An analysis of critical accounting estimate disclosures of pension assumptions. Accounting Horizons, 28(4), 819-845.

Bell, T. B., \& Griffin, J. B. (2012). Commentary on auditing high-uncertainty fair value estimates. Auditing: A Journal of Practice \& Theory, 31(1), 147-155.

Bratten, B., Gaynor, L. M., McDaniel, L., Montague, N. R., \& Sierra, G. E. (2013). The audit of fair values and other estimates: The effects of underlying environmental, task, and auditor-specific factors. Auditing: A Journal of Practice, 32(Supplement 1), 7-44.

Brouwer, A., Eimers, P., \& Langendijk, H. (2016). The relationship between key audit matters in the new auditor's report and the risks reported in the management report and the estimates and judgments in the notes to the financial statements. Maandblad Voor Accountancy en Bedrijfseconomie, 90, 580.

Buchman, T.A., \& Collins, D. (1998). Uncertainty about litigation losses and auditors' modified audit reports. Journal of Business Research, 43, 57-63.

Carson, E., Fargher, N., \& Zhang, Y. (2016). Trends in auditor reporting in Australia: a synthesis and opportunities for research. Australian Accounting Review, 26(3), 226-242.

Christensen, B. E., Glover, S. M., \& Wolfe, C. J. (2014). Do critical audit matter paragraphs in the audit report change nonprofessional investors' decision to invest?. Auditing: A Journal of Practice \& Theory, 33(4), 71-93.

Eilifsen, A., Messier, W.F., Glover, S., \& Prawitt, D. (2010). Auditing \& assurance services, Second International Edition, McGraw Hill, New York.

Francis, J.R., \& Krishan, J. (1999). Accounting accruals and auditor reporting conservatism. Contemporary Accounting Research, 16(1), $135-165$.

Gaynor, L. M., Kelton, A. S., Mercer, M., \& Yohn, T. L. (2016). Understanding the relation between financial reporting quality and audit quality. Auditing: A Journal of Practice \& Theory, 35(4), 1-22.

Glendening, M. (2017). Critical accounting estimate disclosures and the predictive value of earnings. Accounting Horizons, 31 (4), 1-12.

Gold, A., Heilmann, M., Pott, C., \& Rematzki, J. (2020). Do key audit matters impact financial reporting behavior?. International Journal of Auditing, 24(2), 232-244.

Griffith, E. E., Hammersley, J. S., \& Kadous, K. (2015). Audits of complex estimates as verification of management numbers: How institutional pressures shape practice. Contemporary Accounting Research, 32(3), 833-863. 
Grosu, M., Robu, I. B., \& Istrate, C. (2020). The quality of financial audit missions by reporting the key audit matters. Audit Financiar, 18(57). Harsha, P., and Peacock, E. (1989). Auditing accounting estimates. Management Accounting, 71(3), 31-33.

IFRS (2017). Better communication in financial reporting: making disclosures more meaningful. IFRS Foundation Disclosure Initiative-Case Studies. Erişim adresi: https://www.ifrs.org/content/dam/ifrs/project/disclosure-initative/better-communication-making-disclosures-moremeaningful.pdf

Kavut, F. L., \& Güngör, N. (2018). Bağımsız denetimde kilit denetim konuları: BİST-100 şirketlerinin 2017 yılı analizi. Muhasebe Enstitüsü Dergisi, 16(59), 59-70.

Kelton, A. S., \& Montague, N. R. (2018). The unintended consequences of uncertainty disclosures made by auditors and managers on nonprofessional investor judgments. Accounting, Organizations and Society, 65, 44-55.

KGK, (7 Haziran 2019) Finansal raporlamaya ilişkin kavramsal çerçeve (2018 Sürümü), 30794 sayılı Resmi Gazete.

KGK, (24 Mayıs 2018) TMS 1 Finansal tabloların sunuluşu, 30430 sayılı Resmi Gazete.

KGK, (31 Aralık 2019) BDS 540 Muhasebe tahminlerinin ve ilgili açıklamaların denetimi, 30995 (4.M) Sayılı Resmi Gazete.

KGK, (31 Aralık 2019) BDS 701 Kilit denetim konularının bağımsız denetçi raporunda bildirilmesi, 30995 (4.M) Sayılı Resmi Gazete.

Pinello, A., Puschaver, L., \& Volkan, A. (2020). The relationship between critical accounting estimates and critical audit matters. Accounting \& Taxation, 12(1), 23-33.

Sarısoy, Ö., \& Kepçe, N. (2019). Bağımsız denetim raporunda kilit denetim konularına yer verilmesi ve beklenti farkları. Mali Çözüm Dergisi/Financial Analysis, 29(153), 39-66.

Sirois, L. P., Bédard, J., \& Bera, P. (2018). The informational value of key audit matters in the auditor's report: Evidence from an eyetracking study. Accounting Horizons, 32(2), 141-162.

Stuber, S. B., \& Hogan, C. E. (2021). Do PCAOB Inspections Improve the Accuracy of Accounting Estimates?. Journal of Accounting Research, 59(1), 331-370.

Süer, A.Z. (2016). Tahmine dayal finansal raporlama. Eskişehir: Nisan Kitabevi.

Türel, A., \& Türel, A. (2016). Yeni denetim raporlarının finansal iletişime etkileri. Göksel Yücel (Ed.), Seçmeler 2016 kitabı içinde (s. 101-110). İstanbul Üniversitesi, İşletme Fakültesi, Muhasebe Enstitüsü.

Zhang, J., \& Pany, K. (2021). A Summary of Early Critical Audit Matter Reporting. The CPA Journal, 91(2/3), 44-51.

https://www.kap.org.tr/tr/bist-sirketler 
Ek 1

\begin{tabular}{|c|c|c|c|}
\hline Sektör & Şirket & Önemli Muhasebe Tahminleri & KDK* \\
\hline \multirow{7}{*}{$\begin{array}{l}\text { Mali } \\
\text { Kuruluşlar }\end{array}$} & Akbank T.A.Ş. & $\begin{array}{l}\text { Finansal araçların gerçeğe uygun değer hesaplamaları } \\
\text { Finansal varlıkların değer dü̈şüklü̈̆̈̈̈ } \\
\text { Çalışan hakları karş1lığı } \\
\text { Emeklilik hakları } \\
\text { Gayri nakdi krediler beklenen zarar karş1lığı } \\
\text { Diğer karşılıklar (Serbest karş1lıklar, Promosyon karş1lıkları) } \\
\text { Maddi ve maddi olmayan duran varlıkların faydalı ömürleri } \\
\text { Varlıklarda değer düşüklüğü }\end{array}$ & $\checkmark$ \\
\hline & $\begin{array}{l}\text { Doğan Şirketler Grubu } \\
\text { Holding A.Ş. }\end{array}$ & $\begin{array}{l}\text { Devreden katma değer vergisi } \\
\text { Ertelenmiş vergi varlıkları } \\
\text { Şüpheli ticari alacak karşılığı } \\
\text { Yatırım amaçlı gayrimenkuller } \\
\text { İştirak değer düşüklüğü } \\
\text { Kovid-19 Salgınının Grup Faaliyetlerine Etkisi } \\
\text { Şerefiye değer düşüklüğü tespit çalışmaları } \\
\end{array}$ & $\checkmark$ \\
\hline & $\begin{array}{l}\text { Emlak Konut } \\
\text { Gayrimenkul Yatırım } \\
\text { Ortaklığg A.Ş. }\end{array}$ & $\begin{array}{l}\text { Arsa ve konut stoklarının net gerçekleştirilebilir değeri } \\
\text { Dava karşılıkları }\end{array}$ & \\
\hline & $\begin{array}{l}\text { Hacı Ömer Sabanc1 } \\
\text { Holding A.Ş. }\end{array}$ & $\begin{array}{l}\text { Şerefiye } \\
\text { Sandık } \\
\text { Ertelenmiş vergi } \\
\text { Türev araçların ve diğer finansal araçların gerçeğe uygun değerleri }\end{array}$ & $\checkmark$ \\
\hline & Koç Holding A.Ş. & $\begin{array}{l}\text { Sinırsız ömürlü maddi olmayan duran varlıklar değer düşüklüğ̈̈ testleri } \\
\text { Ertelenmiş vergi varlıklarının geri kazanılabilirliği } \\
\text { Sandık karşılı̆̆̆ } \\
\text { Finans sektörü faaliyetlerinden alacaklarda değer düşüklü̈̆̈̈̈: Kredi } \\
\text { riskinde önemli artıs-Niteliksel ve niceliksel değerlendirme-İleriye yönelik } \\
\text { makro ekonomik bilgiler }\end{array}$ & $\begin{array}{l}\checkmark \\
\checkmark \\
\checkmark\end{array}$ \\
\hline & $\begin{array}{l}\text { Tav Havalimanları } \\
\text { Holding A.Ş. }\end{array}$ & $\begin{array}{l}\text { Duyarlılık analizleri: Değer düşüklüğ̈̈̈ analizlerinde kullanılan iskonto } \\
\text { oranlarına ilişkin analizler. Imtiyaz sözleşmelerinden doğan haklar ve } \\
\text { şerefiyenin geri kazanılabilirliği } \\
\text { Maddi ve maddi olmayan duran varlıkların ekonomik ömürleri } \\
\text { İndirgenmiş nakit akımı projeksiyonlarında kullanılan önemli varsayımlar } \\
\text { Kıdem tazminatı karşılığ hesaplanması } \\
\text { Vergi zararlarının ve yatırım indirimlerinin kullanımı } \\
\text { Finansal araçların değerlemesi }\end{array}$ & $\checkmark$ \\
\hline & Tekfen Holding A.Ş. & $\begin{array}{l}\text { Ertelenmiş vergiler } \\
\text { Gelir vergisi } \\
\text { Sözleşme bedeli değişikliği, tamamlanma yüzdesi, inşaat maliyeti } \\
\text { tahminleri } \\
\text { İşverenler tarafından tutulan uzun vadeli maddi teminatlar } \\
\text { Türev araçların ve diğer finansal araçların gerçeğe uygun değerleri }\end{array}$ & $\checkmark$ \\
\hline
\end{tabular}




\begin{tabular}{|c|c|c|}
\hline $\begin{array}{l}\text { Türkiye Garanti Bankası } \\
\text { A.Ş. }\end{array}$ & $\begin{array}{l}\text { Finansal araçların gerçeğe uygun değer hesaplamaları } \\
\text { Beklenen Kredi Zararı Hesaplaması } \\
\text { Şerefiye ve diğer maddi olmayan duran varlıklar } \\
\text { Maddi duran varlıklarda faydalı ömür } \\
\text { Maddi duran varlıklarda değer düşüklüğü } \\
\text { Kıdem tazminatı karş1lıkları } \\
\text { Devre esas emeklilik yükkümlülüklerinin net bugünkü değeri } \\
\text { Kiralama işlemleri }\end{array}$ & $\begin{array}{l}\checkmark \\
\checkmark\end{array}$ \\
\hline Türkiye Halk Bankası A.Ş. & $\begin{array}{l}\text { Finansal varlıkların gerçeğe uygun değeri } \\
\text { Finansal varlık ve yükümlülüklerin ölçüm kategorileri } \\
\text { Finansal varlıklarda değer düşüklü̆̈̈̈-beklenen kredi zararı hesaplaması } \\
\text { Şerefiye ve diğer maddi olmayan duran varlıklar } \\
\text { Karşılıklar ve koşullu yükümlülükler } \\
\text { Çalışan haklarına ilişkin yükümlülükler } \\
\text { Emeklilik haklarından doğan yükümlüllükler } \\
\text { Kiralama işlemleri }\end{array}$ & $\checkmark$ \\
\hline Türkiye İş Bankası A.Ş. & $\begin{array}{l}\text { Finansal varlıklarda değer düşüklü̆̆̈̈̈-beklenen kredi zararı hesaplaması } \\
\text { Şerefiye ve diğer maddi olmayan duran varlıklar } \\
\text { Maddi duran varlıklarda faydalı ömür } \\
\text { Maddi duran varlıklarda değer düşüklüğü } \\
\text { Sigorta teknik karş1lıkları } \\
\text { Karş1lıklar ve koşullu yükümlülükler } \\
\text { Kıdem tazminatı karş1lıkları } \\
\text { Emeklilik haklarından doğan yükümlülükler }\end{array}$ & $\checkmark$ \\
\hline $\begin{array}{l}\text { Türkiye Sınai Kalkınma } \\
\text { Bankası A.Ş. }\end{array}$ & $\begin{array}{l}\text { Finansal varlıklarda değer düşüklü̈̆̈̈̈-beklenen kredi zararı hesaplaması } \\
\text { Maddi duran varlıklarda faydalı ömür } \\
\text { Maddi duran varlıklarda değer düşüklüğü } \\
\text { Karş1lıklar ve koşullu yükümlülükler } \\
\text { Çalışan haklarına iliş̧kin yükümlülükler }\end{array}$ & $\checkmark$ \\
\hline $\begin{array}{l}\text { Türkiye Şişe ve Cam } \\
\text { Fabrikaları A.Ş. }\end{array}$ & $\begin{array}{l}\text { Ertelenmiş vergi varlığ } \\
\text { TMS } 16 \text { kapsamında yeniden değerleme modeli ile değerleme } \\
\text { TMS } 36 \text { kapsamında varlıklarda değer düşüklüğ̈̈ } \\
\text { TMS } 40 \text { kapsamında muhasebeleştirilen gayrimenkullerde yeniden } \\
\text { değerleme }\end{array}$ & $\checkmark$ \\
\hline $\begin{array}{l}\text { Türkiye Vakıflar Bankası } \\
\text { T.A.O. }\end{array}$ & $\begin{array}{l}\text { Finansal varlıklarda değer düşüklüğ̈̈̈-beklenen kredi zararı hesaplaması } \\
\text { Şerefiye ve diğer maddi olmayan duran varlıklar } \\
\text { Maddi duran varlıklarda faydalı ömür } \\
\text { Maddi duran varlıklarda değer düşüklüğ̈̈ } \\
\text { Karşılıklar ve koşullu yükümlülükler } \\
\text { Kıdem tazminatı karş1lıkları } \\
\text { Sigortacılık faaliyetleri } \\
\text { Emeklilik haklarından doğan yükümlülükler }\end{array}$ & $\checkmark$ \\
\hline $\begin{array}{l}\text { Yapı ve Kredi Bankası } \\
\text { A.Ş. }\end{array}$ & $\begin{array}{l}\text { Finansal varlıklarda değer düşüklü̆ğ̈̈-beklenen kredi zararı hesaplaması } \\
\text { Diğer maddi olmayan duran varlıklar } \\
\text { Maddi duran varlıklarda faydalı ömür } \\
\text { Maddi duran varlıklarda değer düşüklüğ̈̈ } \\
\text { Karş1lıklar ve koşullu yükümlülükler } \\
\text { Kıdem tazminatı karş1lıkları } \\
\text { Sigortacılık faaliyetleri } \\
\text { Emeklilik haklarından doğan yükümlülükler }\end{array}$ & $\checkmark$ \\
\hline
\end{tabular}




\begin{tabular}{|c|c|c|c|}
\hline \multirow{5}{*}{ İmalat } & Arçelik A.Ş. & $\begin{array}{l}\text { Sınırsı faydalı ömre sahip olan maddi olmayan duran varlıklar ve şerefiye } \\
\text { değer dü̧̈üklü̈̆̈̈ tespit çalışması } \\
\text { Kıdem tazminatı karşılığı } \\
\text { Faydalı ömür } \\
\text { Garanti gider karşılıkları }\end{array}$ & $\checkmark$ \\
\hline & $\begin{array}{l}\text { Ereğli Demir ve Çelik } \\
\text { Fabrikaları T.A.Ş. }\end{array}$ & $\begin{array}{l}\text { Maddi ve maddi olmayan duran varlıkların faydalı ömürleri } \\
\text { Ertelenmiş vergi } \\
\text { Türev finansal araçların rayiç değerleri } \\
\text { Şüpheli alacak karş1lığ1 } \\
\text { Stok değer düşüklüğü karşılığ1 } \\
\text { Çalışanlara sağlanan faydalara ilişkin yükümlülükler } \\
\text { Dava karşılıkları } \\
\text { Varlıklarda değer düşüklüğü } \\
\text { Finansal varlıklarda değer düşüklüğü } \\
\text { Zarar karşıllı̆ı hesaplaması }\end{array}$ & \\
\hline & Gübre Fabrikaları T.A.Ş & $\begin{array}{l}\text { Net gerçekleşebilir değer } \\
\text { Şerefiye değer düşüklüğü } \\
\text { Ertelenmiş vergi } \\
\text { Gayrimenkullerin gerçeğe uygun değeri }\end{array}$ & $\checkmark$ \\
\hline & $\begin{array}{l}\text { Kardemir Karabük Demir } \\
\text { Çelik Sanayi ve Ticaret } \\
\text { A.Ş }\end{array}$ & $\begin{array}{l}\text { Kurum Kazancı Üzerinden Hesaplanan Vergiler } \\
\text { Şüpheli Alacak Karş1lıları } \\
\text { Dava Karşılıkları } \\
\text { Maddi ve Maddi Olmayan Duran Varlıkların ve Yatırım Amaçlı } \\
\text { Gayrimenkullerin Ekonomik Ömürleri } \\
\text { Ertelenmiş Vergi } \\
\text { Türev Araçların ve Diğer Finansal Araçların Gerçeğe Uygun Değerleri }\end{array}$ & \\
\hline & $\begin{array}{l}\text { Oyak Çimento Fabrikaları } \\
\text { A.Ş. }\end{array}$ & $\begin{array}{l}\text { Şüpheli alacak karşılıkları } \\
\text { Dava karşılıkları } \\
\text { Maddi, maddi olmayan duran varlıkların ve yatırım amaçlı gayrimenkullerin } \\
\text { ekonomik ömürleri } \\
\text { Çalışanlara sağlanan faydalar } \\
\text { Rehabilitasyon karşılığı } \\
\text { Maden ruhsat hakları } \\
\text { Maden ocakları karşılığ1 } \\
\text { Edim yükümlülüklerinin yerine getirilme } \text { zamanının belirlenmesindeki } \\
\text { hükümler } \\
\text { Stok değer düşüklüğü karşıllı̆ı } \\
\text { Ertelenmiş Vergi } \\
\text { Türev araçların gerçeğe uygun değerleri }\end{array}$ & $\checkmark$ \\
\hline
\end{tabular}




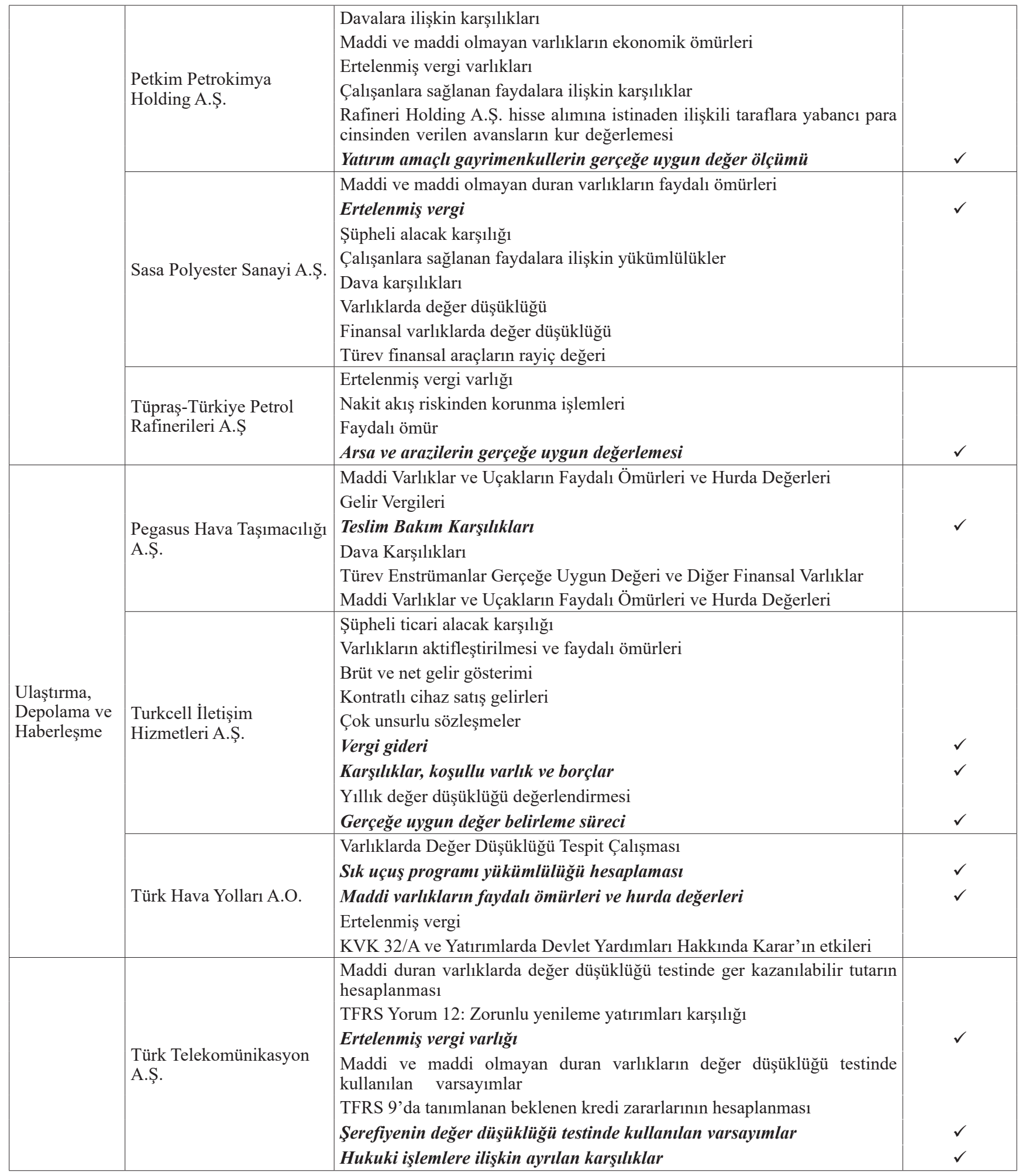




\begin{tabular}{|c|c|c|c|}
\hline \multirow{2}{*}{$\begin{array}{l}\text { Madencilik } \\
\text { ve Taş } \\
\text { Ocakçıllğ } 1\end{array}$} & $\begin{array}{l}\text { Koza Altın İşletmeleri } \\
\text { A.Ş. }\end{array}$ & $\begin{array}{l}\text { Karşılıklar, Koşullu varlık ve yükümlülükler, Rehabilitasyon karş1lığ } 1 \\
\text { Maddi ve maddi olmayan duran varlıkların değer düşüklüğü } \\
\text { Maden varlıkları } \\
\text { Maden arama, değerlendirme ve geliştirme giderleri } \\
\text { Kiralamayı uzatma veya sonlandırma opsiyonlarına ilişkin önemli } \\
\text { varsayımlar ve tahminler } \\
\text { Beklenen Kredi Zararları Karşıllığ1 }\end{array}$ & $\checkmark$ \\
\hline & $\begin{array}{l}\text { Koza Anadolu Metal } \\
\text { Madencilik İşletmeleri A.Ş }\end{array}$ & $\begin{array}{l}\text { Maden varlıkları } \\
\text { Maden varlıklarının amortismanı } \\
\text { Çevre rehabilitasyonu, maden sahalarının ıslahı ve kapanması istinaden } \\
\text { finansal tablolara yansıtılan karşılık tutarları } \\
\text { Ertelenmiş vergi varlığı } \\
\text { Yasal riskler } \\
\text { Dava karşılıkları }\end{array}$ & $\checkmark$ \\
\hline Teknoloji & $\begin{array}{l}\text { Aselsan Elektronik Sanayi } \\
\text { ve Ticaret A.Ş. }\end{array}$ & $\begin{array}{l}\text { Ertelenmiş vergi } \\
\text { Çalışanlara sağlanan faydalara ilişkin karşılıklar } \\
\text { Maddi ve maddi olmayan duran varlıkların faydalı ömürleri } \\
\text { Eskalasyon } \\
\text { Garanti gider karşılığı } \\
\text { Geliştirme giderleri }\end{array}$ & $\checkmark$ \\
\hline Ticaret & $\begin{array}{l}\text { Bim Birleşik Mağazalar } \\
\text { A.Ş. }\end{array}$ & $\begin{array}{l}\text { Çalışanlara sağlanan faydaların muhasebeleştirilmesi } \\
\text { Stok karşılıkları } \\
\text { Gerçeğe uygun değer farkı diğer kapsamlı gelire yansıtılan finansal } \\
\text { varlıkların gerçeğe uygun değerinin belirlenmesi } \\
\text { Bina ve arsaların yeniden değerlenmesi } \\
\text { Maddi ve maddi olmayan varlıkların ekonomik ömürleri } \\
\text { Kullanım hakkı varlık ve yükümlülüklerinin hesaplamasında nakit } \\
\text { akışlarının bilanço tarihine indirgenmesinde kullanılan yıllık iskonto } \\
\text { oranının ve kiralama süresinin belirlenmesi } \\
\text { Gelir vergisi karşılıkları }\end{array}$ & $\checkmark$ \\
\hline
\end{tabular}

*Kilit denetim konuları (KDK) 
